\author{
2. To: (Receiving Organization) \\ B-Cell Cleanout Project \\ 5. Proj./Prog./Dept./Div.: \\ Projects 19300 \\ 8. Originator Remarks: \\ Review \& approve
}

3. From: (Originating Organization)

AST Remote Deployment Project

Efottex 6. Design Authority/Dosign Agent/Cog. Engr.:

4. Related EDT No.:
N/A
7. Purchase Order No.:
N/A
9. Equip./Component No.:
N/A
10.

10. System/Bldg./Facility:

N/A

12. Major Assm. Dwg. No.:

N/A

13. Permit/Permit Application No.:

$\mathrm{N} / \mathrm{A}$

14. Required Response Date:

August 16, 1999

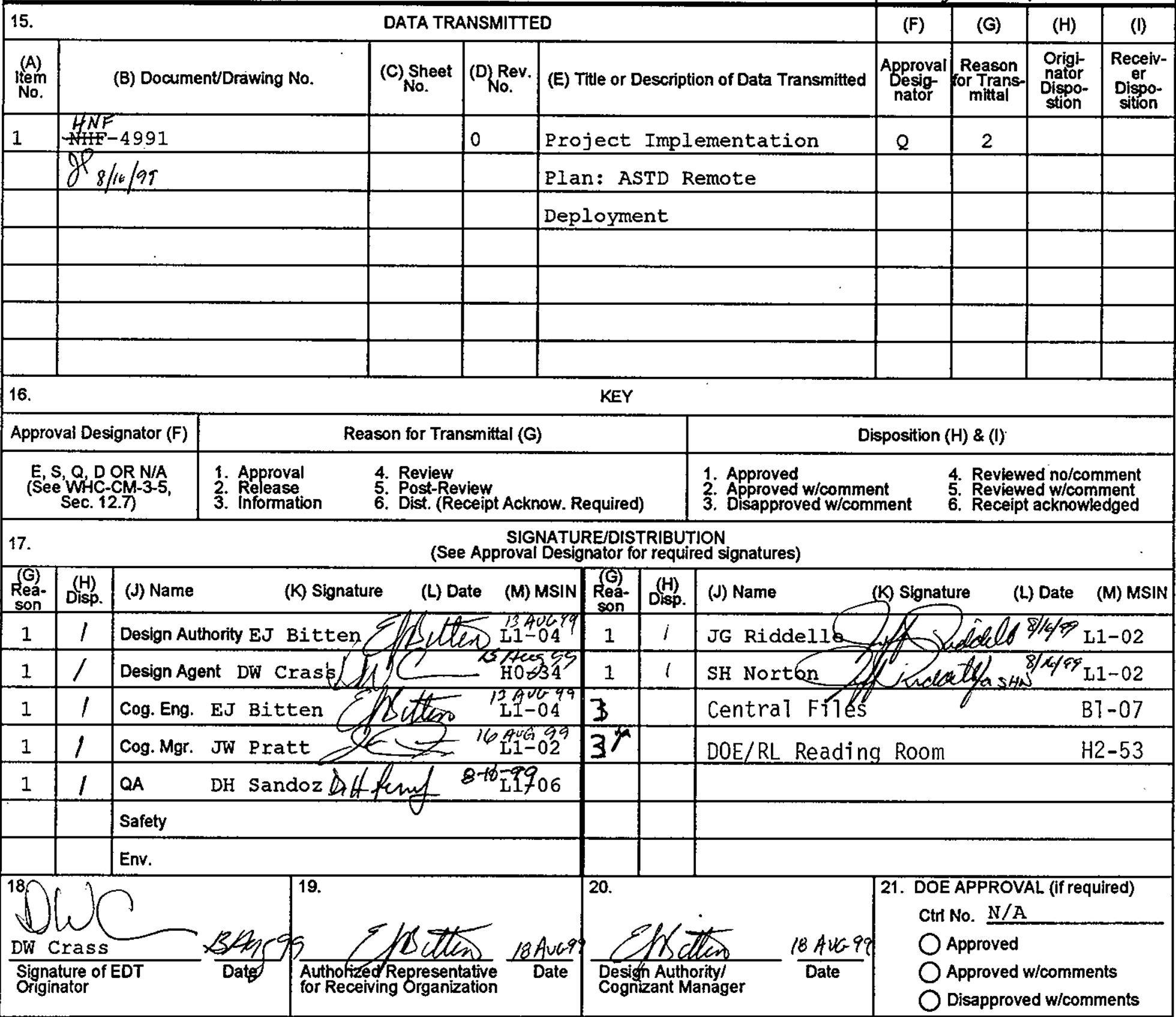




\title{
PROJECT IMPLEMENTATION PLAN: ASTD REMOTE DEPLOYMENT
}

D. พ. Crass

Numatec Hanford Corporation

Richland, WA 99352

U.S. Department of Energy Contract DE-AC06-96RL13200

EDT/ECN: 627027

Org Code: 82000

B\&R Code: EW3110022
UC: 2080

Charge Code: $109134 / B 000$ fa HN990151 Total Pages: $\quad 36$

Key Words: Project Plan, ASTD, B-Cell, 324 Building, Remote Procurement

\begin{abstract}
:
This document is the project implementation plan for the ASTD Remote Deployment Project. The Plan identifies the roles and responsibilities for the project and defines the integration between the ASTD Project and the B-Cell Cleanout Project.
\end{abstract}

TRADEMARK DISCLAIMER. Reference herein to any specific commercial product, process, or service by trade name, trademark, manufacturer, or otherwise, does not necessarily constitute or imply its endorsement, recommendation, or favoring by the United States Government or any agency there of or its contractors or subcontractors.

Printed in the United States of America. To obtain copies of this document, contact: Document Control Services, P.O. Box 950, Mailstop H6-08, Richland WA 99352, Phone (509) 372-2420; Fax (509) 376-4989.

$\frac{\text { fanis Rasdal } 8-18-99}{\text { Date }}$

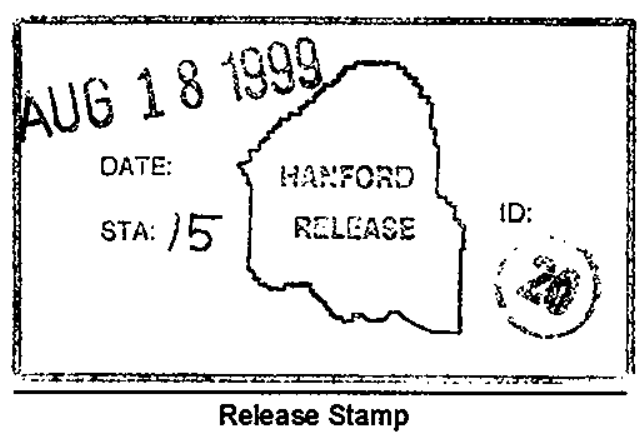




\section{PROJECT IMPLEMENTATION PLAN: ASTD REMOTE DEPLOYMENT}

(Remote/Robotic Work Platform Procurement for Large Hot Cell Deactivation)

D. W. Crass

August 1999 


\section{TABLE OF CONTENTS}

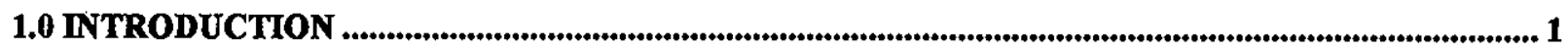

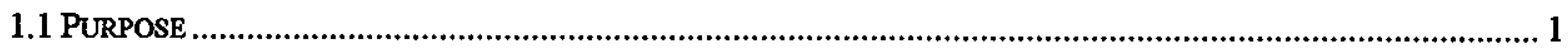

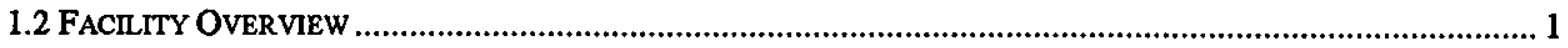

1.3 SCOPE

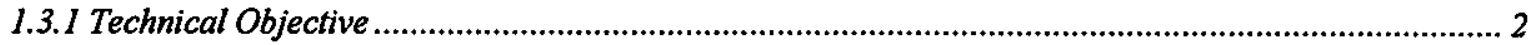

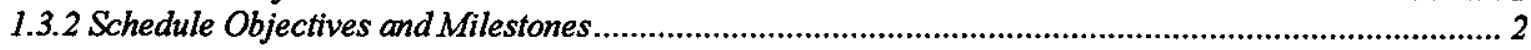

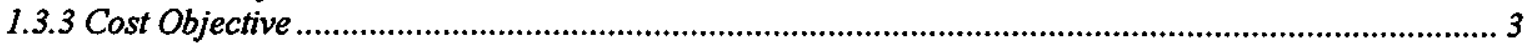

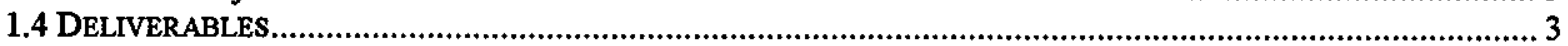

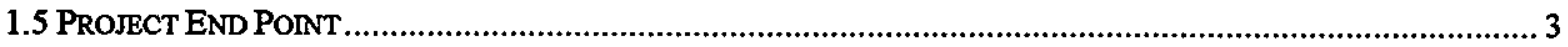

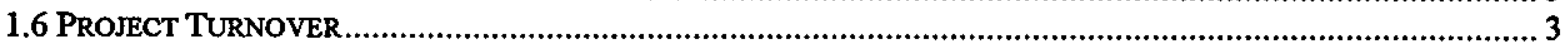

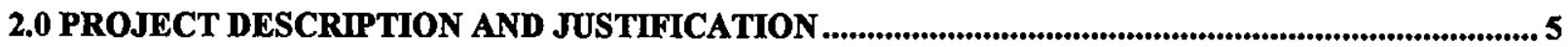

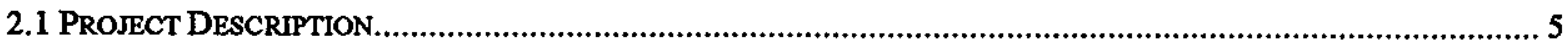

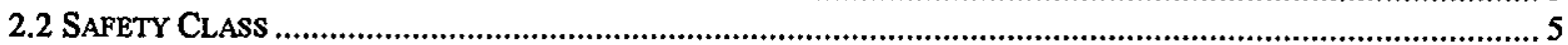

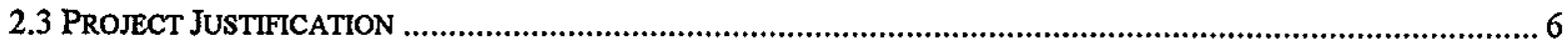

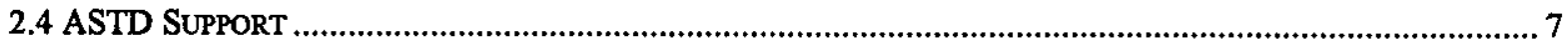

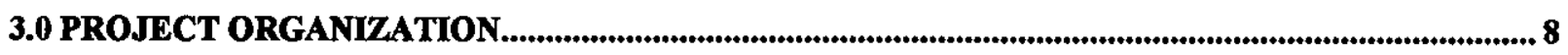

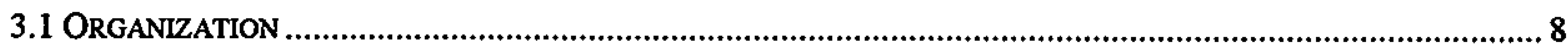

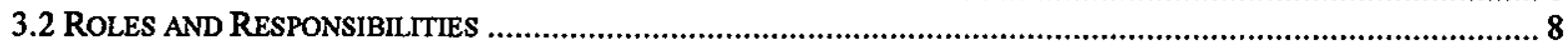

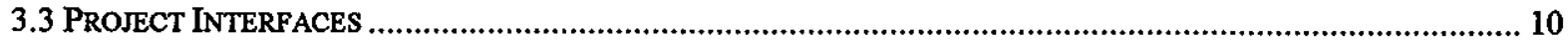

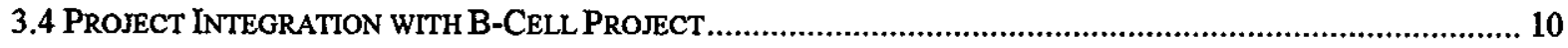

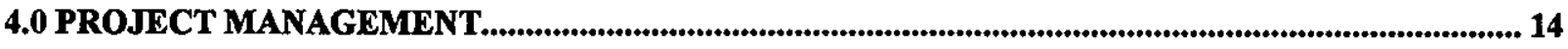

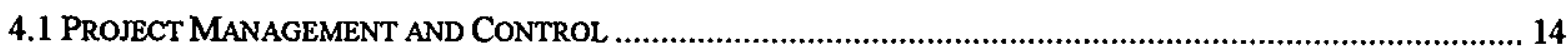

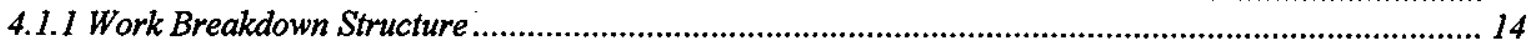

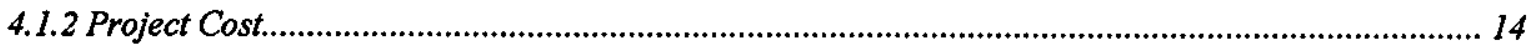

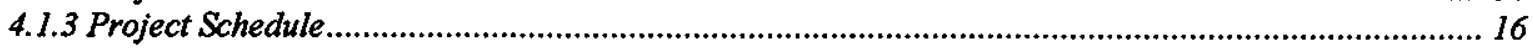

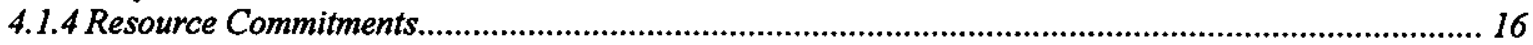

4.1.5 Project Risk/Quality Level Determination ................................................................................... 16

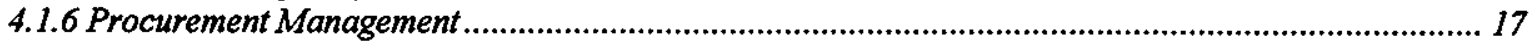

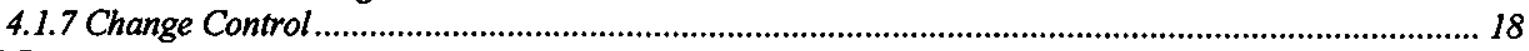

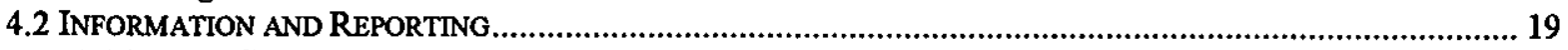

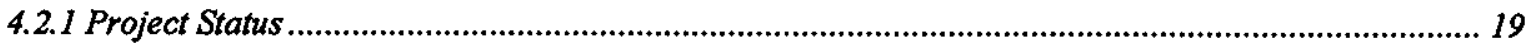

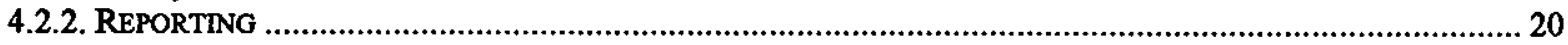

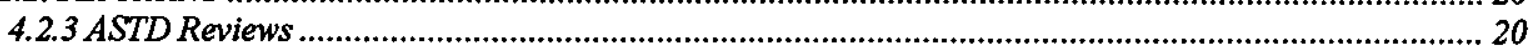

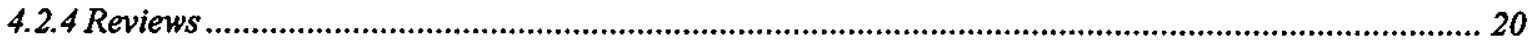

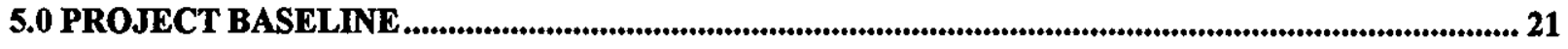

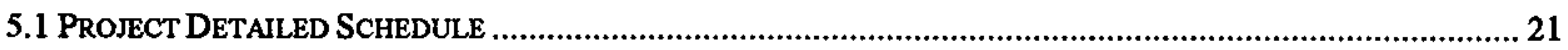

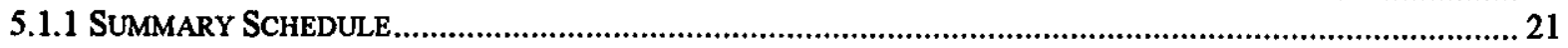

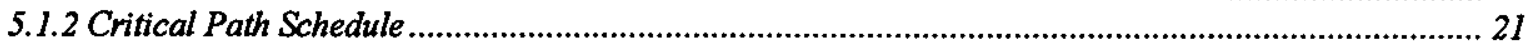

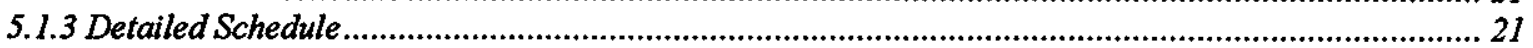

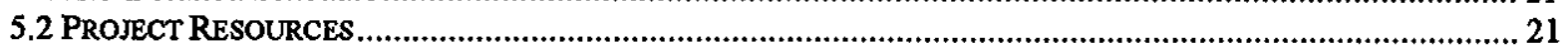

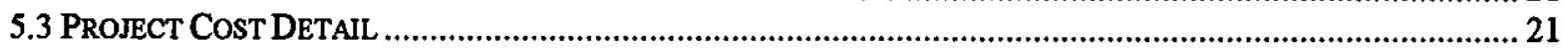

6.0 TRANING

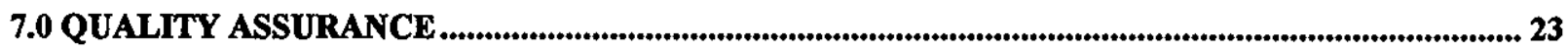

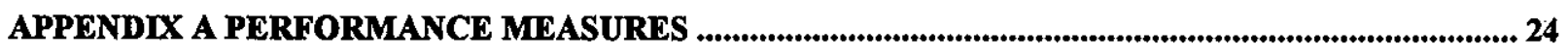

APPENDIX B CHECKLIST FOR PROJECT TURNOVER AND ACCEPTANCE ................................... 26 
HNF-4991, Rev. 0

APPENDIX C ASTD REMOTE DEPLOYMENT PROJECT ORGANIZATION ................................... 27

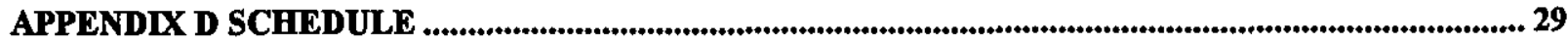


HNF-4991, Rev. 0

\subsection{INTRODUCTION}

This Project Implementation Plan (PIP) shall be the controlling document for the Accelerated Site Technology Deployment (ASTD) supported project to procure and qualify a remote/robotic work platform for large hot cell deactivation in the 324 Building B-Cell. This plan will be integrated into the 324/327 Buildings Stabilization/Deactivation Project, Project Management Plan, (HNFIP- 1289, Rev. 1) and shall comply with the base requirements established in that document. This PIP establishes the baseline and defines the scope, schedule, budget, organizational responsibilities, reporting requirements, deliverables, and end points for the implementation of new technology into B-Cell. This shall include procurement, safety, quality assurance, training, documentation, record management, and facility modifications applicable to this project.

Specifically this plan controls and executes the procurement and acceptance, qualification, and turnover of a remote/robotic work platform for 324 Building B-Cell. This includes the development of functional parameters, performance requirements, evaluation criteria, procurement specifications, acceptance and qualification test procedures, training requirements, and turnover responsibilities.

\subsection{Purpose}

The 324/237 Buildings Stabilization/Deactivation Project is currently in its second year of a nine-year project to complete deactivation and closure of the facility for long-term surveillance and maintenance. A major obstacles for the project is the inability to effectively perform deactivation tasks within high radioactively contaminated hot cells. The current strategies utilize inefficient and resource intensive technologies that significantly impact the cost and schedule for stabilization and deactivation. The ASTD Remote Deployment Project shall identify, procure, and turnover, to the B-Cell project, a remote/robot work platform to improve $B-C e l l$ cleanup productivity and enhance worker safety and health.

\subsection{Facility Overview}

The 324 Building was constructed as a Waste Technology Engineering Laboratory, containing Radiochemical Engineering Cells (REC) used for high-radiation, high-contamination chemical process development and demonstrations. B-Cell is in the largest REC, measuring $301 / 2$ feet (9.3 meters) high with a floor dimensions of 25 feet ( 7.6 meters) by 22 feet $(6.7$ meters). The cell was used for vitrification testing during its operation, with approximately 70 million total curies passing through the cell. Cell dose rates average $3000 \mathrm{R} / \mathrm{hr}(30 \mathrm{~Gy} / \mathrm{hr})$ with hot spots up to $10,000 \mathrm{R} / \mathrm{hr}(100 \mathrm{~Gy} / \mathrm{hr})$.

The B-Cell clean up effort includes removal of all excess equipment, fuel bundles, and all dispersible and adherent waste material. The cell will be decontaminated using mechanical and chemical techniques. The integrity and condition of the stainless steel liner will be determined, consistent with the 324 Building Radiochemical Engineering Cells, High Level Vault, Low Level Vault and Associated Areas Closure Plan, DOE/RL-98-73, Rev. 1. Potentially the cell liner and contaminated underlying concrete may be removed. 
HNF-4991, Rev. 0

\subsection{Scope}

Establish an ASTD Remote Deployment Project team integrated with the 324 Building B-cell Project to procure and turnover to B-Cell, a remote/robotic deactivation technology compatible with project goals and milestones. The technology will be capable of performing stabilization and deactivation activities that are commensurate with the B-Cell project needs at the time of deployment.

\subsubsection{Technical Objective}

Procure demonstrated off the shelf remote/robotic work platform in 324 Building B-Cell beginning fiscal year (FY) 2001. Functional and operational requirements will be developed by the B\&W Hanford, Company (BWHC) ASTD Remote Deployment Project Team and supported by the existing B-Cell Safety Cleanup Project (BCCP). The remote/robotic work platform will possess full reach capability within B-Cell, will be capable of deploying several tools or end effectors to accelerate work tasks, and will eliminate the need for multiple specialized tool design and procurement. These activities could include such tasks as size reduction, debris collection and packaging, deployment of visual inspection systems, liner repair, and deployment of decontamination methods.

\subsubsection{Schedule Objectives and Milestones}

Objectives

- Issue Request for Proposal (RFP)

- Award Contract

- Fabrication/Assembly of System

- Personnel Training and Qualification

- Facility Preparations

- Cold Testing and Evaluation

- Low Radiation Testing (if necessary)

- Turnover to B-Cell Project

ASTD Milestones (Reference: TTP RL09DD61)

Milestone 1- Finalize System Procurement Specification

Milestone 1A- Issue Second Request for Information (RFI)

Milestone 2- Issue Request for Proposal (RFP)

Milestone 3- Award Contract for Robotic Work Platform

Milestone 4- Accept Robotic Work Platform to Ship to Hanford

Milestone $5 *$ - Complete Installation of Robotic Work Platform in the 324 Building
July1999

October 1999

November 1999 - July 2000

January 2000 - September 2000

July 1999 - August 2000

May 2000 - July 2000

July 2000 - September 2000

September 29, 2000

June 30, 1999

July 30, 1999

September 7, 1999

October 15, 1999

July 15,2000

September 30, 2000

* Milestone 5 will be completed by B-Cell Cleanout Project. Milestones 1 through 4 will be completed by the ASTD Remote Deployment Project. 
HNF-4991, Rev. 0

\subsubsection{Cost Objective}

The total cost for the project is estimated to be over (See Section 2.4) $\$ 4,048,900$. ASTD funding for this project is $\$ 1,544,800$. The BCCP will provide $\$ 2,504,400$ in leveraged funds from its current baseline budget. Availability of this leveraged funding is based upon current project funding profiles.

ASTD (EM-50) funds finance the procurement of a remote/robotic platform. In addition ASTD funds support pre-deployment activities, personnel training, procedure development, acceptance testing, spare part procurement, and on-site operational testing as a prerequisite for turnover and in-cell deployment of the remote/robotic system by the B-Cell Project.

Leveraged funds from the BCCP will be used for pre-deployment activities, operator training, procedure development, maintenance training, and B-Cell modifications supporting installation of the work platform.

\subsection{Deliverables}

- Procurement specification - June 30, 1999

- Establish vendor selection list- July 30, 1999

- Issue RFP to selected vendors- September 7, 1999

- Contract Award- October 15, 1999

- Remote/robotic work platform delivered on site- July 14,2000

- Turnover to B-Cell Project- September 29, 2000

Appendix A. identifies the performance measures established in the ASTD Deployment Plan, Deploying a Robot Work Platform for Large Hot Cell Deactivation, January 1999. These performance measures shall be considered project deliverables.

\subsection{Project End Point}

The ASTD Remote Deployment Project will deliver an operational qualified work platform for installation into B-Cell by September 29, 2000. The work platform will be installed and operated by the BCCP. The work platform shall be capable of performing deactivation activities that are commensurate with the B-Cell project schedule at the time of installation. The requirements and deactivation activities that the work platform shall be capable of performing will be defined, documented, and approved by the BCCP Manager. Acceptance of the work platform by the BCCP shall be considered the ASTD Project end point.

\subsection{Project Turnover}

Prior to delivery of the work platform on site, a project Turnover and Acceptance checklist will be developed and approved by the ASTD Remote Deployment Project Manager and the BCCP Manager. Appendix B serves as a guide for developing a project turnover and acceptance checklist. The Turnover and Acceptance checklist shall identify and track all relevant documentation, training, facility support, and facility modifications necessary to deploy the system into B-Cell. The checklist shall provide visibility of roles, responsibilities, and participation in the activities supporting turnover of the completed system. The checklist will 
support project planning by providing a written agreement with the end user (B-Cell Safety Cleanup Project) of what constitutes the project end point deliverables and project closure and will support a smooth transition of ownership from the project to the end user.

The ASTD Remote Deployment Project shall be responsible for performing and validating final operational/qualification testing onsite prior to turnover to the BCCP. 
HNF-4991, Rev. 0

\subsection{PROJECT DESCRIPTION AND JUSTIFICATION}

\subsection{Project Description}

The ASTD Remote Deployment Project will identify, procure, and turnover to the BCCP, a remote/robotic work platform in the 324 Building B-Cell. The project will develop a Request for Proposal (RFP) and procurement specification that will define the functional requirements, performance parameters, and evaluation criteria to deploy a work platform that is compatible with B-Cell operations and cleanup commitments.

The scope of the project shall include:

- Establishment and management of the baseline requirements

- Engineering studies related to the definition and development of system requirements

- Evaluation of available technologies

- Assure appropriate Quality Assurance Requirements are applied

- Acceptance and qualification test procedures and criteria

- Acceptance and qualification test reports

- Operating and training procedures

- Training of hot cell technicians, operators, and maintenance personnel

- Maintenance procedures

- Identification and procurement of spare parts

- Design and fabrication of mockup facilities

- Identification of B-Cell modifications related to the installation of the work platform

- Support B-Cell Project for installation and deployment activities

The ASTD Remote Deployment Project shall be responsible for identifying and procuring a remote/robotic work platform for the BCCP including vendor information, procedures, and other support data. The work platform shall be capable of performing two of the deactivation and decommissioning operations identified in the ASTD Deployment Plan, Deploying a Robot Work Platform for Large Hot Cell Deactivation, January 1999. The BCCP Project Manager will identify two technology needs commensurate with project goals and schedule opportunities at the time of delivery. These activities may include remote size reduction of remaining process equipment and systems, visual inspection of the interior cell liner, debris removal and packaging, decontamination of interior cell surfaces, and repair and potential removal of the cell liner.

\subsection{Safety Class}

A preliminary Hazards Safety Analysis will be conducted, based on the functions and requirements defined in the Remote Work Platform specification HNF-4640. The Hazards Safety Analysis will be documented in the project files. A preliminary Hazards Safety Analysis has identified the Work Platform as a general service system. Unreviewed Safety Question (USQ) screenings, evaluations, and other safety analyses will be performed as needed, to support procurement and installation. 
HNF-4991, Rev. 0

\subsection{Project Justification}

The current mission of the 324/327 Buildings Stabilization/Deactivation Project is to accomplish the safe, cost effective, deactivation, using innovative technologies that eliminate or mitigate all building risks. The end result is a stable facility condition requiring minimal and low cost surveillance and maintenance.

Deactivation and clean up of the 324 Building B-Cell supports the U.S. Department of Energy (DOE) mortgages reduction goals. The Remote/Robot Work Platform being procured through the auspices of ASTD will accelerate B-Cell Project schedules, reduce cost and schedule impacts, and satisfy Hanford deactivation, decontamination and decommissioning project needs for the 324 Building. These needs have been identified in the:

- Hanford Science and Technology Needs Statements (DOE/RL-98-01, Revision 1),

- 324/327 Buildings Stabilization/Deactivation Project, Project Management Plan (HNF-IP-1289, Rev.1),

- 324 Building Radiochemical Engineering Cells, High-Level Vault, Low-Level Vault, and Associated Areas Closure Plan (DOE/RL-98-73, Rev. 1).

- TPA Milestones:

- M-89-00 Complete Closure of Non-permitted MW Units in the 324 REC, HLV and LLV. A completion date will be established immediately following Ecology approval of the REC, HLV and LLV closure plan (DOE/RL-96-73). Completion date is to be determined.

- M-89-02 Complete removal of the 324 Building B-Cell mixed waste and equipment, by November 30, 2000.

Current B-Cell deactivation and clean up actions are performed using master-slave manipulators and overhead bridge cranes. Manipulators mounted on the upper third of the cell wall can not reach the lower 8-10 feet (2.3-3 meters) of the walls and provide no access to the cell floor. The cranes provide floor access but deactivation activities and tasks are severely limited. Neither system allows access to the upper portion of the cell, cell liner, or ceiling.

Additionally, visibility is hampered by the limited light transmission through the thick lead glass windows and the large size of the hot cell. This problem has been partially solved using in-cell radiation hardened video cameras. However, the visual resolution is low and they do not allow viewing of all work areas.

Deployment of a remote/robotic work platform will have the potential to perform an array of deactivation tasks such as mechanical and chemical decontamination, equipment size reduction, visual inspection, cell liner integrity verification, cell liner repair and removal, and debris/dispersible collection. Considerable reductions in personnel radiation dose exposure and in the project cost and schedule will be realized by deploying this remote/robotic system. Table 1 provides an example of tooling and end effectors, which could potentially be deployed. 
HNF-4991, Rev. 0

Table 1. Remote/Robotic Tooling and End Effectors

\begin{tabular}{|l|l|l|}
\hline Impact wrenches & Pipe cutters & Chemical decon equipment \\
\hline Hydraulic shears & Lights & Spraying gear \\
\hline Electric circular saws & Plasma arc torch & Grinders \\
\hline Electric reciprocating saws & $\begin{array}{l}\text { Mechanical decon } \\
\text { equipment }\end{array}$ & $\mathrm{CO}_{2}$ blast \\
\hline $\begin{array}{l}\text { Two or more mounted video } \\
\text { cameras with integral lighting unit }\end{array}$ & Media blast equipment & Ultra-High Press water \\
\hline
\end{tabular}

Advantages for using a remote/robotic system are:

- Improved access to all areas of B-Cell.

- Visual access to all areas within the cell.

- Position or support additional camera and visual inspection equipment for specific deactivation activities.

- Reduce radiation exposures associated with manipulator removal, decontamination, and repair.

- Increased productivity.

- Increased equipment reliability.

- Adaptable/flexible system increases the capability to perform required deactivation and stabilization operations.

\subsection{ASTD Support}

The cost of this project to procure and deploy the remote/robotic system is estimated to be over $\$ 4,048,900$. Of this amount, EM-50 will fund $\$ 1,544,800$, primarily for the procurement of off the shelf technology to accelerate B-Cell deactivation activities. All of EM-50 funds dedicated to the project will be obligated in FY 1999 and FY 2000. 


\subsection{PROJECT ORGANIZATION}

\subsection{Organization}

Appendix C ASTD Remote Deployment Project Organization

\subsection{Roles and Responsibilities}

Table 2 identifies the responsible personnel and the established points-of-contact for this ASTD project. The BWHC point of contact for this procurement of the remote/robotic system is J. W. Pratt. The manager responsible for the BCCP is J. G. Riddelle. The DOE Headquarters (HQ) point of contact is J. R. Duda.

Table 2. Responsible Persons and Points-of-Contact

\begin{tabular}{|l|l|c|}
\hline DOE HQ & EM-50 ASTD Point of Contact & John R. Duda \\
\hline DOE RL & $\begin{array}{l}\text { Assistant Manager for Facility } \\
\text { Transition (EM-60) }\end{array}$ & Peter M. Knollemeyer \\
\hline & $\begin{array}{l}\text { Assistant Manager for Science } \\
\text { and Technology (EM-50) }\end{array}$ & Robert M. Rosselli \\
\hline & ASTD Project Oversight & David C. Langstaff \\
\hline & EM-50 D\&D Liaison & Dennis A. Brown \\
\hline Fluor Daniel Hanford, Inc. & $\begin{array}{l}\text { Facility Stabilization Project } \\
\text { Director (EM-60) }\end{array}$ & Larry J. Olguin \\
\hline & $\begin{array}{l}\text { Technology Management } \\
\text { Oversight (EM-50/60) }\end{array}$ & Gregory T. Berlin \\
\hline B\&W Hanford Company & $\begin{array}{l}\text { President and General } \\
\text { Manager }\end{array}$ & Arthur Clark \\
\hline & $\begin{array}{l}\text { 324/327 Buildings } \\
\text { Stabilization/Deactivation } \\
\text { Project Director }\end{array}$ & Jim M. Steffen \\
\hline & $\begin{array}{l}\text { B-Cell Safety Cleanup Project } \\
\text { Manager }\end{array}$ & Jeffery G. Riddelle \\
\hline & $\begin{array}{l}\text { ASTD Project Integration } \\
\text { Manager }\end{array}$ & Jeff Pratt \\
\hline & 300 Area Quality Assurance & Dave Sandoz \\
\hline & Design Authority & Ernie J. Bitten \\
\hline & Cog Engineer & Ernie J. Bitten \\
\hline & & \\
\hline
\end{tabular}


Table 3. Responsible Persons and Approval Authority

\begin{tabular}{|c|c|c|c|c|c|c|c|c|c|c|}
\hline & & 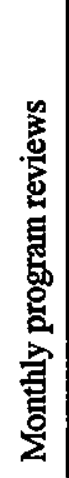 & 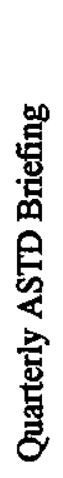 & 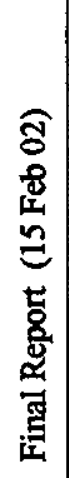 & 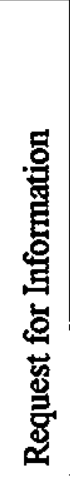 & 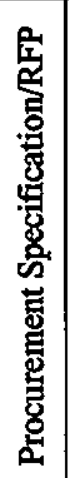 & 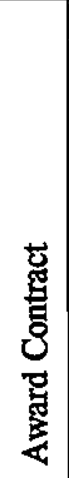 & 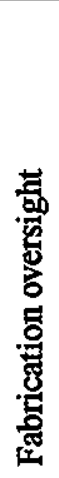 & 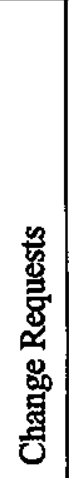 & 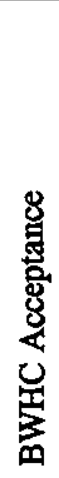 \\
\hline DOE HQ & John R. Duda & & I & I & & & & & & \\
\hline \multirow[t]{4}{*}{ DOE RL } & $\begin{array}{l}\text { Peter M. } \\
\text { Knollemeyer }\end{array}$ & & I & $\mathbf{A}$ & & & & & & \\
\hline & Robert M. Rosselli & & I & $\mathbf{A}$ & & & & & & \\
\hline & David C. Langstaff & I & $\mathbf{A}$ & $\mathbf{A}$ & & I & $\mathbf{I}$ & & & \\
\hline & Dennis A. Brown & I & I & $\mathrm{I}$ & & & I & & & \\
\hline $\begin{array}{l}\text { Fluor Daniel Hanford, } \\
\text { Inc. }\end{array}$ & Larry J. Olguin & & $\mathbf{I}$ & A & & & $\mathbf{I}$ & & & \\
\hline Numatec Hanford Corp. & Gregory T. Berlin & & $\mathbf{R}$ & $\mathbf{R}$ & $\mathbf{I}$ & $\mathbf{R}$ & $\mathbf{R}$ & & I & $\mathrm{I}$ \\
\hline \multirow[t]{6}{*}{$\begin{array}{l}\text { B\&W Hanford } \\
\text { Company }\end{array}$} & Arthur Clark & & $\mathbf{I}$ & A & & & I & & & \\
\hline & Jim Steffen & I & $\mathrm{A}$ & $\mathrm{A}$ & $I$ & $\mathbf{A}$ & $\mathrm{A}$ & $I$ & $\mathrm{I}$ & $I$ \\
\hline & Jeffery G. Riddelle & $\mathbf{A}$ & $\mathbf{A}$ & $\mathbf{A}$ & $\mathbf{A}$ & $\mathbf{A}$ & $\mathbf{A}$ & $\mathbf{A}$ & $\mathrm{A}$ & $\mathbf{A}$ \\
\hline & Jeff Pratt & $\mathbf{A}$ & $\mathbf{A}$ & $\mathrm{A}$ & $\mathbf{A}$ & $\mathbf{A}$ & $\mathbf{A}$ & A & A & \\
\hline & Emest J. Bitten & $\mathbf{P}$ & $\mathbf{P}$ & $\mathbf{P}$ & $\mathbf{P}$ & $\mathbf{P}$ & $\mathbf{P}$ & $\mathbf{P}$ & $\mathrm{P}$ & $\mathbf{P}$ \\
\hline & Dave Sandoz & & & $\mathbf{R}$ & $\mathbf{R}$ & $\mathbf{A}$ & & $\mathbf{A}$ & $\mathbf{A}$ & $\mathbf{A}$ \\
\hline
\end{tabular}

$\mathbf{P}=$ Prepare $\quad \mathrm{R}=$ Review/comment $\mathbf{A}=$ Approve $\mathbf{I}=$ Information

\subsection{Project Interfaces}

The ASTD Remote Deployment Project is a subtier project of the 324 Building BCCP. As such the B-Cell Project Manager is responsible for integrating project activities into the BCCP Project baseline. The ASTD Remote Deployment Project PIP shall be released as a Hanford document and referenced in the 324/327 Buildings StabilizationDeactivation Project, Project Management Plan. This PIP shall provide the basis for a formal baseline change request for the B-Cell Safety Cleanup Project during the FY 2000 Multi Year Work Plan (MYWP) process. 
Major participants in the ASTD Remote Deployment Project include the DOE HQ (EM-50 Division), RL (EM-60), BWHC and other Project Hanford Management Contract (PHMC) Major Subcontractors. The organizational relationships, roles and responsibilities of these major project participants are summarized in Tables 2 and 3 above.

In addition, the project will interface and coordinate activities with the following 324 Building facility organizations:

- 324 Building B-Cell Safety Cleanup Project

- Facility Operations

- Facility Maintenance

- Facility Engineering

- Facility Radiation Engineering and Protection

- BWHC Procurement

- Quality Assurance

- Project Controls

- Training

- Environmental

Interfacing organizations will commit to and provide the resources as identified in the project resource loaded schedule to assure successful integration of the remote/robot work platform into B-Cell.

\subsection{Project Integration with B-Cell Project}

The ASTD Remote Deployment Project is a subproject supporting the BCCP. The work platform will be procured to support 324 Building B-Cell cleanup activities and milestones. System requirements will be established to support existing BCCP tasks and commitments, and the BCCP Manager will have final approval of the RFP and procurement specification.

Programmatic and operational responsibilities for the remote/robot work platform is the jurisdiction of the BCCP and falls within the purview of the overall 324/327 Buildings Stabilization/ Deactivation Project. The 300 Area Facility Director for Stabilization/Deactivation provides direct programmatic ownership of the ASTD project. The sponsoring group provides programmatic integration and operations liaison support between the ASTD project and 324 Building projects. The ASTD Project team will provide day-to-day project management oversight and technical direction for the procurement and turnover of the remote/robot work platform.

Specific programmatic and project management responsibilities associated with the ASTD Remote Deployment Project include the following:

\section{Programmatic Responsibilities (BCCP)}

- Provide the technical baseline, and establish functional and operational requirements as they apply to B-Cell cleanup goals and commitments. 
- Provide operations liaison between the project and facility personnel to minimize interface problems, promote integration, and facilitate project implementation. The BCCP shall provide operations liaison support and represent ASTD interests as they relate to the remote/robot work platform during upper level project reviews, meetings, and other activities.

- Provide programmatic, technical/engineering, operations, safety, environmental, health physics, and craft personnel, as required, to support procurement, testing, pre-installation activities, installation, and turnover of completed systems.

- Ensure timely exchange of information, data, records, and guidelines for special conditions/requirements that may impact project cost (e.g., functional and operational requirements, safety, QA, and training requirements, etc.) to the ASTD Project Manager.

- Participate and concur with final inspection and acceptance testing, and accept completed systems for operation.

- Support the development of operator procedures and training for operations and maintenance personnel, as required.

- Ensure integration of the ASTD Project with the 300 Area Stabilization Projects.

\section{Project Management Responsibilities (ASTD Remote Deployment Project)}

- Manage authorized project funds/resources, and approve project cost/schedule baselines.

- Provide for development, approval, and release of project documents.

- Provide technical direction to support the project technical baseline and safety basis for procurement.

- Provide technical/engineering personnel as required.

- Coordinate with BWHC Procurement

- Ensure vendor proposal and contract award is compliant with the project baselines, with consideration for safety, ALARA, quality, operability, maintainability, environmental compliance, and cost effectiveness factors. Provide contract technical approval. Involve the interfacing organizations in project development and reviews, as appropriate, and ensure documented closeout of all comments.

- Provide administration of the project baseline to assure appropriate management of scope, cost, and schedule commitments using the change control process. Approve all baseline changes. 
- Act as a focal point to coordinate and integrate participating contractors and subcontractors for project activities. Provide appropriate direction to assure compliance with the project technical baseline and other technical design criteria.

- Provide project oversight to optimize the procurement in terms of quality, safety, cost, reliability, maintainability, life cycle costs, environmental requirements, accuracy, and assure compliance with applicable codes, standards, criteria, regulations, and DOE Orders

- Provide informational copies of project associated correspondence, reports, drawings, specifications, nonconformance reports, plans and schedules, cost estimates, QA records, audits, subcontracts, minutes, test procedures, photographs, etc., to other PHMC team members as required.

- Coordinate meetings and provide timely notification of meetings (with agenda when applicable), scheduled acceptance tests, and final inspections to participants and other appropriate parties.

- Prepare data input for monthly project reviews and reports, as required.

- Provide appropriate level of oversight for work performed by other contractors for the project.

- Coordinate installation, training, and testing activities with 324 Building personnel (Operations Person-In-Charge, Health Physics, Industrial Safety, etc.)

- Perform/document risk management activities.

- Provide technical support for vendor reviews, testing, training, and installation associated with the implementation of the work platform into B-Cell.

- Interface with EM-50. 


\subsection{PROJECT MANAGEMENT}

\subsection{Project Management and Control}

The technical baseline defines the required functional, operational, and performance criteria to meet the project end point goals. The activities necessary to provide the end product shall be determined using the technical baseline. This scope of work is divided into elements that become the work breakdown structure (WBS) and are used as the basis for the cost and schedule baselines.

\subsubsection{Work Breakdown Structure}

The project WBS will be developed to provide a basis for scope definition, resource planning, and project control. The WBS will provide the flexibility to identify discreet project tasks and activities and the ability to link these together using schedule logic to reflect the planned order in which the actual work will be completed.

WBS dictionaries and basis of estimates prepared for the ASTD Remote Deployment Project will be formatted for inclusion into the BCCP schedule and the 324/327 Buildings Stabilization/Deactivation Project PMP. The dictionaries will include a summary-level statement of the technical scope, key milestones, key interfaces, and subproject assumptions. Lower-level WBS dictionaries can be developed at the discretion of the ASTD Project Manager.

\subsubsection{Project Cost}

The cost of this project to procure and deploy the remote/robotic system is estimated to be over $\$ 4,048,900$. Of this amount, EM-50 will fund $\$ 1,544,800$. The remainder $(\$ 2,504,400)$ will be leveraged from of the BCCP baseline operating funds for the and cleanup and closure of BCell. Availability of this leveraged funding is based upon current project funding profiles. All of the EM-50 funds dedicated to the project will be obligated in FY 1999 and FY 2000. Table 4 shows the estimated project costs and funding source associated with this ASTD project. 
HNF-4991, Rev. 0

Table 4. Project Costs and Funding (\$1,000s)

\begin{tabular}{|c|c|c|c|c|c|}
\hline Ceos 1103 & W & Whor & (2) & 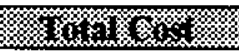 & 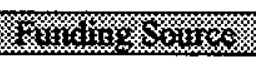 \\
\hline (1) & & & & & \\
\hline Procurement of remote platform & $1,100.0$ & 0 & 0 & $1,100.0$ & ASTD \\
\hline \multirow[t]{2}{*}{ Training and procedure development } & 0 & 67.2 & $\overline{0}$ & 67.2 & ASTD \\
\hline & 0 & 26.9 & 264.8 & 291.7 & 324 Project \\
\hline \multicolumn{6}{|l|}{ 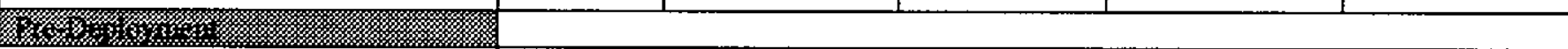 } \\
\hline \multirow[t]{2}{*}{ Pre-deployment Activities } & $\mathbf{0}$ & 63.0 & 0 & 63.0 & ASTD \\
\hline & 55.9 & 20.4 & 105.5 & 181.8 & 324 Project \\
\hline \multirow[t]{2}{*}{ Installation Activities } & 0 & 144.4 & 0 & 144.4 & ASTD \\
\hline & 0 & 40.0 & 0 & 40.4 & 324 Project \\
\hline \multirow[t]{2}{*}{ Operational acceptance activities } & 0 & 68.0 & $\overline{0}$ & 68.0 & ASTD \\
\hline & $\mathbf{0}$ & 45.0 & 0 & 45.0 & 324 Project \\
\hline \multirow[t]{2}{*}{ Procurement of spare parts } & 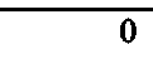 & 75.0 & $\mathbf{0}$ & 75.0 & $\overline{\text { ASTD }}$ \\
\hline & 0 & 86.5 & 271.2 & 357.7 & 324 Project \\
\hline \multirow[t]{2}{*}{ Maintenance } & 0 & 27.2 & $\mathbf{0}$ & 27.2 & ASTD \\
\hline & 0 & 15.3 & 200.8 & 216.1 & 324 Project \\
\hline \multicolumn{6}{|l|}{ 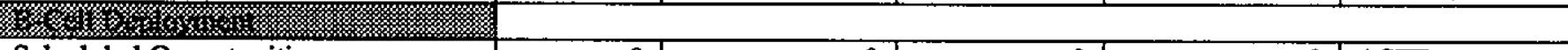 } \\
\hline Scheduled Opportunities & 0 & 0 & 0 & 0 & ASTD \\
\hline Scheduled Opportunities & $\mathbf{0}$ & 49.4 & $1,322.4$ & $1,371.8$ & 324 Project \\
\hline \multicolumn{2}{|l|}{$\frac{1}{4}$} & $\sqrt{3}+3$ & 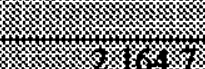 & & 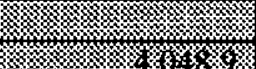 \\
\hline 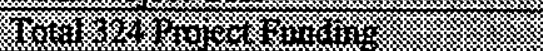 & 3.30 & l> & 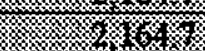 & & (2.25 \\
\hline 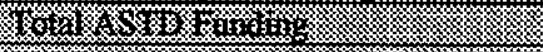 & 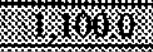 & 1. & & & 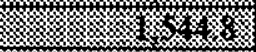 \\
\hline (j) & & & & & 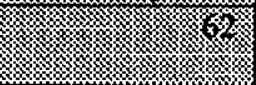 \\
\hline
\end{tabular}


HNF-4991, Rev. 0

\subsubsection{Project Schedule}

The ASTD Project team will develop subproject schedules at a level that allows for providing performance measures and decision-making (i.e., inter- or intra-subproject prioritization).

Schedule development and maintenance include assessing the impact of factors such as delays, equipment failures, procurement lead-time, productivity, resource availability and constraints, and facility availability. In addition, the project critical path will be identified and maintained on an on-going basis. Schedules will be statused monthly to effectively manage and integrate inter- and intra-subproject activities. The ASTD Project Manager will identify issues and concerns that may affect key milestones, performance agreements, and higher level deliverables; or affect the critical path of the project. Corrective action plans will be developed as required.

\subsubsection{Resource Commitments}

The 324/327 Buildings Stabilization/Deactivation Project Director shall assign and commit 324 Building and BCCP resources as identified in the project resource loaded schedule.

\subsubsection{Project Risk/Quality Level Determination}

The Primary assumptions established for this project plan are:

- Procurement cost (ASTD funds) will be adequate to procure a system that meets BCell closure goals.

- ASTD funding is received by April 1, 1999 and funding commitment remains at $\$ 1,544,800$.

- BCCP will receive the necessary resource and budget commitment to complete the project.

- BCCP schedules will remain consistent with the baseline established in this PIP.

- The 324/327 Buildings Stabilization/Deactivation Project Director shall assign and commit 324 Building and BCCP resources as identified in the project resource loaded schedule.

- Estimated ASTD and BCCP funding is adequate for procuring and supporting predeployment activities at a level appropriate for the technology/robot.

Project risk for the ASTD Remote Deployment Project has been identified as:

- Procurement cost (ASTD funding) was estimated on incomplete functional and performance requirements.

- Original ASTD proposal was submitted for a crane deployed two arm robotic system. Commercial technology may not be available to meet project goals.

The Quality Level established for the procurement of the Remote/Robot Work Platform is QL-3. The determination for QL is based on an evaluation of the BCCP risk associated with the procurement, installation, and deployment of the Work Platform and the completed 
Hazards Analysis checklist in accordance with HNF-PRO-704. The risk to the BCCP caused by delays in deployment or failure of the equipment is considered to be low. Justification for this determination is:

Project schedule- the BCCP baseline schedule is based on current methods and equipment for completing B-Cell project goals. The deployment of the Work Platform will accelerate the project schedule. Delay of the procurement, deployment or failure of the system will not impact the current BCCP baseline.

Project cost- the BCCP baseline cost is based on current methods and equipment for completing B-Cell project goals. Current baseline estimates include funding for multiple equipment development, testing, and deployment to complete baseline activities. Procurement of the Work Platform will reduce or eliminate the need to develop multiple tools and support equipment. Delay of the procurement, deployment or failure of the system will not impact the current BCCP baseline.

Safety- failure or delay of deployment will not impact the safety of the facility or critical support systems. Failure or delay of the deployment will not effect worker safety or health. Failure or delay of the deployment will not affect public safety or health. Failure or delay of deployment will not impact the environment.

A Safety Hazards Analysis has determined that deployment of the system will not effect safety class SSCs within the 324 building. A determination, based on the Safety Hazards Analysis has classified the Work Platform as General Service.

The Cognizant Engineer and the Cognizant QA Engineer concluded that the Quality Level be elevated to QL3 due to the high visibility nature of the ASTD procurement and the desire to establish specific Quality Requirements such as hold points, vendor Quality Program verification, and inspections.

\subsubsection{Procurement Management}

Procurement management shall be performed in accordance with site Major Subcontractor procedures to ensure all practices are in compliance with Federal Acquisition Regulations (FAR). The ASTD Remote/Robotic Work Platform will be procured in accordance with requirements for procuring commercial items as specified in FAR part 12.

Procurement of the Remote/Robot Work Platform will be a two step procurement process

- solicitation of technically qualified vendors through a RFI

- Issuing a RFP for competitive bid.

The procurement strategy followed by the ASTD Deployment Project will:

- Identify potential vendors and issue a RFI.

- Finalize a performance based procurement specification.

- Issue a second RFI to selected technically qualified vendors

- Establish a Technical Evaluation Team. 
HNF-4991, Rev. 0

- Solicit interested vendors to attend a one-on-one meeting to:

- Perform market research

- Discuss specification requirements

- Ensure the vendor fully understands the specification and project requirements

- Discuss vendors proposal

- Evaluate proposals and concepts with respect to:

- Vendor technical capability

- Ability to meet the specification requirements

- Finalize specification based on vendor discussions.

- Issue RFP to qualified vendors for competitive bid. (minimum of two)

- Award contract

Table 3 identifies the responsible persons and approval authority for procurement related documentation.

Issuing a finalized performance specification as a second RFI will allow the ASTD project team to perform a comprehensive market search and interact with selected vendors via a one-on-one technology exchange. After issuing the second RFI, meetings will be scheduled with individual vendors. Solicitation of vendors to participate in one-on-one meetings will allow the project team to clarify project and technical requirements. Potentially the specification may be revised based on vendor input and capabilities of current commercially available technology. A Technical Evaluation Team will be established by the project to conduct meetings with solicited vendors. The team will consist of QA, B-Cell Project, technical, and procurement personnel. Upon completion of each formal vendor meeting the Evaluation Team will perform a technical evaluation of the vendor. After all vendors have been interviewed the Evaluation Team will prepare a "short list" of vendors to be issued a RFP. Proposals submitted in response to the RFP will be evaluated for price and technical accuracy, and a vendor selected for the procurement. The evaluation will be documented in the project files.

Technical evaluation criteria will be developed prior to conducting vendor interviews. The evaluation criteria will be based on the requirements established in the procurement specification and will include, technical design (capability to meet the performance parameters identified in the procurement specification), quality assurance, schedule, vendor experience and capability, and the vendor's ability to provide training and technical support . Vendor provided technical support, both before and after deployment of the system, is an essential aspect of this procurement. The objective of this procurement strategy will be to establish a successful working relationship with the vendor.

\subsubsection{Change Control}

Baseline change control will be administered in accordance with Hanford Site procedure HNFPRO-533. Responsibilities and requirements for management, administration, and use of the technical, schedule, and cost baseline control system will be implemented in accordance with HNF-PRO-533. 
HNF-4991, Rev. 0

\subsubsection{Cost and Schedule Change Control}

Estimates for the total project cost have been developed and presented in the ASTD Deployment Plan (January 1999). This includes both the ASTD supported funds and the BCCP leveraged funds. The project baseline will be established using a detailed resource loaded schedule and will be documented through the MYWP.

Justification for change will be submitted through a Baseline Change Request (BCR). The ASTD Integrated Project Manager and the BCCP Project Manager must approve all baseline changes. Specific baseline change control requirements shall be managed in accordance with BWHC change control guidelines and specific requirements established for the 324/327 Building Stabilization/Deactivation Project and the BCCP.

\subsubsection{Technical Baseline Change Control}

The technical baseline will be established during the procurement phase of the project and will be defined by the procurement specification for the remote/robotic platform. The specification will identify the :

- Technical specifications

- Functional requirements

- Operational requirements

- Safety/ALARA requirements

- Performance requirements

- Decontamination requirements

- Maintenance requirements

- Quality Assurance requirements

Changes to the technical and cost/schedule baselines will be controlled through an Engineering Change Notice (ECN) and BCR. Changes to the technical baseline will be reviewed and approved by the BCCP Project Manager and ASTD Remote Deployment Project Manager.

\subsection{Information and Reporting}

\subsubsection{Project Status}

The ASTD Remote Deployment Project Manager will report on technical issues, resolution, accomplishments, schedule, performance, and cost monthly. Schedule status will be assessed based on earned value. The ASTD Remote Deployment Project Manager will determine the status of work completed in the past month and work in progress, and identify work scheduled the following month. Variance reports will be issued for each reporting period, which identify cost and schedule performance, accomplishments, technical issues, and resolution. 
An estimate at completion (EAC) will be developed, beginning no later than July 1999, for the current fiscal year activities and project life-cycle activities. The EAC will be based on detailed analysis of performance data and variances, and relevant changes to the baseline. Development of the EAC should be an ongoing process, with updated information provided through monthly status.

\subsubsection{Reporting}

The project team's monthly report shall be a progress report that includes the cost performance, milestone schedule status, variance analysis, and issues. The report will be presented monthly to the BCCP Project Manager and ASTD Remote Deployment Project Manager.

In addition, project status will be reported monthly to EM-50 through the Progress Tracking System (PTS). The PTS report will summarize performance and compare it with the technical, schedule, and cost baselines.

\subsubsection{ASTD Reviews}

Throughout the project, BWHC will provide regular (typically quarterly, scheduled by RL) EM-50 ASTD program management review meetings. The appropriate personnel from DOE-HQ, RL, FDH and BWHC will attend the meetings. These meetings will be held at the ASTD project site in Richland, Washington, or via telecom.

BWHC will be responsible for preparing and issuing the agenda and recording action items, agreements, and commitments that result from the meeting. Quarterly reviews will focus on significant accomplishments, expected accomplishment for the next quarter; major problems and issues facing the project; and current cost, schedule, and technical status.

As required, the ASTD Remote Deployment Project Manager shall represent BWHC to support FDH and RL to conduct special-topic project meetings to review progress, identify issues and action items requiring management decisions, change actions, and other items as necessary.

\subsubsection{Reviews}

BWHC and RL will conduct a monthly project status review. The review will focus on significant accomplishments since the last review; expected accomplishments for the next quarter; major problems and issues facing the project; and current cost, schedule, and technical status.

The monthly meeting will also focus specifically on tracking the progress and future potential deployment opportunities. Specific requirements, constraints or criteria previously identified by the future deployment sites' representatives will be discussed and results/resolutions provided, as they become available. 


\subsection{PROJECT BASELINE}

The final baseline for the ASTD Remote Deployment Project will be developed during the FY 2000 MYWP process.

\subsection{Project Detailed Schedule}

Will be developed during the FY 2000 MYWP and/or Formal Baseline Change Request process.

\subsubsection{Summary Schedule}

See Appendix D

\subsubsection{Critical Path Schedule}

Will be developed during the FY 2000 MYWP and/or Formal Baseline Change Request process.

\subsubsection{Detailed Schedule}

Will be developed during the FY 2000 MYWP and/or Formal Baseline Change Request process.

\subsection{Project Resources}

Will be developed during the FY 2000 MYWP and/or Formal Baseline Change Request process.

\subsection{Project Cost Detail}

Will be developed during the FY 2000 MYWP and/or Formal Baseline Change Request process. 


\subsection{TRAINING}

The ASTD Remote Deployment Project shall use existing BCCP requirements and procedures to establish training qualifications. The Project shall assure that documented and approved training and qualification procedures are provided to BCCP prior to commencement of work platform operations. 324 Hot Cell Operations shall assure that all operators and shift supervisors are offered training to perform assigned tasks in a manner that minimizes personnel risk and minimizes impacts to the public, the environment; and the building and associated equipment. 


\subsection{QUALITY ASSURANCE}

The ASTD Remote Deployment Project is a subproject of the BCCP. As such, it will be bound by the Quality Assurance requirements established in HNF-IP-1264 Section 8.1, Rev. 0, Project Quality Assurance Program Plan (QAPP). The QAPP is a supplement to, and must be used in conjunction with the BWHC Facility Stabilization Project QAPP, FSP-MP-004.

HNF-IP-1264, Rev. 0 applies to all Project quality-affecting activities governed by the PHMC Quality Assurance Program Description (QAPD), HNF-MP-599, that affect, or potentially affect, quality-related items.

The 300 Area Project Quality Assurance organization shall be responsible for:

- Interpreting and invoking QA requirements through HNF-IP-1264, Rev. 0, and Project- specific implementing documents.

- Reviewing and approving documents (e.g., design documents, procurement documents, and procedures.)

- Overview, assessing, and verifying compliance with applicable QA requirements.

- Support inspection and acceptance testing to verify quality.

- Assisting the Project to establish and maintain procedures for implementing applicable QA requirements.

The Project shall comply with PHMC and BWHC procedures that implement applicable QA Requirements identified in the "QAPD Project Implementation Matrix in 8.1 and BWHC Implementation Matrix in FSP-004. Work shall be stopped per HNF-MD-035, "Shutdown and Stop-Work Direction", for conditions adverse to Quality.

The QA Program requirements shall be selected and applied to specific Project activities and items using a graded approach. The graded approach shall be implemented by assigning the appropriate safety classification (SS, SC, GS, or NA) of items and activities based upon the criteria established in HNF-IP-1264 Section 8.1, Rev. 0.

Noncompliance with applicable QA requirements, when discovered through assessments, investigations of events, or other means, shall be identified and reported in accordance with HNF-IP-1264, Sections 2.22 and 2.6. 
HNF-4991, Rev. 0

APPENDIX A PERFORMANCE MEASURES 
Performance Measures Tracking Table

\begin{tabular}{|c|c|c|c|c|}
\hline Task/Activity & Performance Measure & Scheduled Completion & $\begin{array}{l}\text { Actual Performance } \\
\text { (to be completed during } \\
\text { deployment of the project) }\end{array}$ & Actual Completion \\
\hline Procure a remote/robotic system & $\begin{array}{l}\text { Complete vendor qualifications and delivery of demonstrated, commercially } \\
\text { available remote/robotic work platform, including all ancillary equipment and } \\
\text { infrastructure. }\end{array}$ & April 2000 & & \\
\hline $\begin{array}{l}\text { Satisfy facility requirements for } \\
\text { deactivation and support baseline } \\
\text { project activities }\end{array}$ & $\begin{array}{l}\text { Perform activities and tasks currently identified in the } 324 \text { Building B-Cell } \\
\text { baseline schedule. }\end{array}$ & December 2002 & & \\
\hline $\begin{array}{l}\text { Minimize personnel exposure to } \\
\text { nuclear/radioactive hazards }\end{array}$ & $\begin{array}{l}\text { Reduce the number of airlock entries associated with the repair of the overhead } \\
\text { cranes and master-slave manipulators. Provide a reliable remote/robotic system } \\
\text { that can support airlock activities. }\end{array}$ & & & \\
\hline Provide full cell accessibility & $\begin{array}{l}\text { Install remote work platform in building } 324 \text { Building B-Cell. Operate the system } \\
\text { to demonstrate reach capability provides full access the in-cell stainless steel liner. }\end{array}$ & July 2000 & & \\
\hline \multicolumn{5}{|c|}{$\begin{array}{l}\text { Deployment of the remote/robotic work platform in } 324 \text { Building B-Cell will demonstrate and perform two of the following facility stabilization tasks in cell. The two tasks will be determined by project needs based on current } \\
\text { schedule status at the time of deployment. The remainder of the stabilization tasks will be performed commensurate with project baseline schedules under the deployment phase of this proposal. }\end{array}$} \\
\hline Size reduction & $\begin{array}{l}\text { Install the work platform in building } 324 \text { Building B-Cell. Demonstrate size } \\
\text { reduction capability utilizing specialty end effectors or end effectors that } \\
\text { accommodate current cell methods such as plasma arc torch or circular grinders. }\end{array}$ & TBD & & \\
\hline Mechanical Decontamination & $\begin{array}{l}\text { Install the work platform in building } 324 \text { Building B-Cell. Demonstrate } \\
\text { mechanical decontamination capability utilizing specialty end effectors or end } \\
\text { effectors that accommodate current cell methods or specialized decontamination } \\
\text { systems provided by the B-Cell project. }\end{array}$ & TBD & & \\
\hline Chemical Decontamination & $\begin{array}{l}\text { Install the work platform in building } 324 \text { Building B-Cell. Demonstrate chemical } \\
\text { decontamination capability utilizing specialty end effectors, or end effectors, } \\
\text { which accommodate current, cell methods or specialized decontamination systems } \\
\text { provided by the B-Cell project. }\end{array}$ & TBD & & \\
\hline Visual inspection & $\begin{array}{l}\text { Install the work platform in building } 324 \text { Building B-Cell. Demonstrate visual } \\
\text { inspection capability utilizing specialty end effectors and visual systems or end } \\
\text { effectors that accommodate commercially available visual systems. }\end{array}$ & TBD & & \\
\hline Liner repair & $\begin{array}{l}\text { Install the work platform in building } 324 \text { Building B-Cell. Demonstrate liner } \\
\text { cutting, size reduction and removal capability utilizing specialty end effectors or } \\
\text { end effectors which accommodate current cell methods such as plasma arc torch or } \\
\text { circular grinders. }\end{array}$ & TBD & & \\
\hline Debris/Dispersible removal & $\begin{array}{l}\text { Install the work platform in building } 324 \text { Building B-Cell. Demonstrate size } \\
\text { reduction capability utilizing specialty end effectors or end effectors which } \\
\text { accommodate current cell methods such as plasma arc torch or circular grinders }\end{array}$ & TBD & & \\
\hline
\end{tabular}




\section{APPENDIX B CHECKLIST FOR PROJECT TURNOVER AND ACCEPTANCE}

Program/Project Title:

\begin{tabular}{|c|c|c|c|}
\hline DESCRIPTION & RESPONSIBIUTY & DESCRIPTION & RESPONSIBIUTY \\
\hline 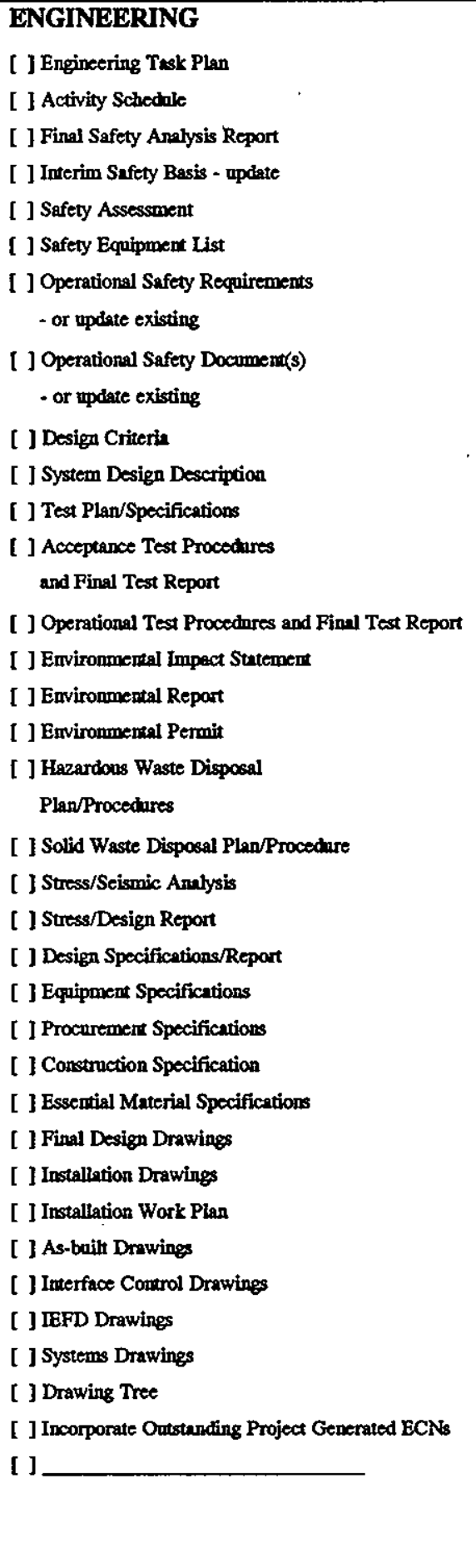 & · & 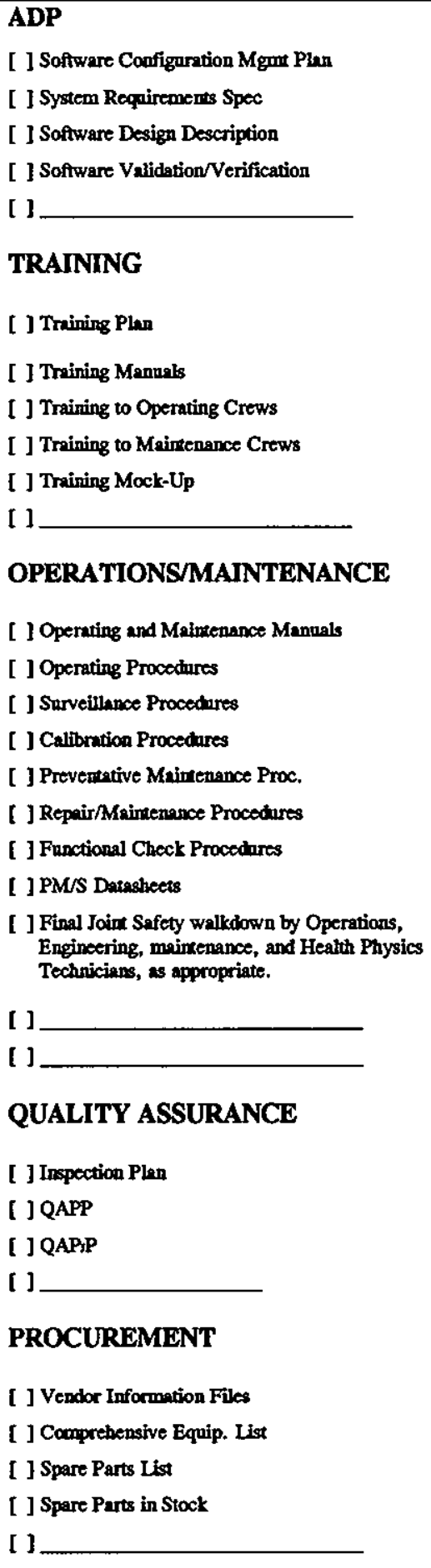 & \\
\hline
\end{tabular}


HNF-4991, Rev. 0

APPENDIX C ASTD REMOTE DEPLOYMENT PROJECT ORGANIZATION 


\section{ASTD IMPLEMENTATION PROJECT ORGANIZATION CHART}

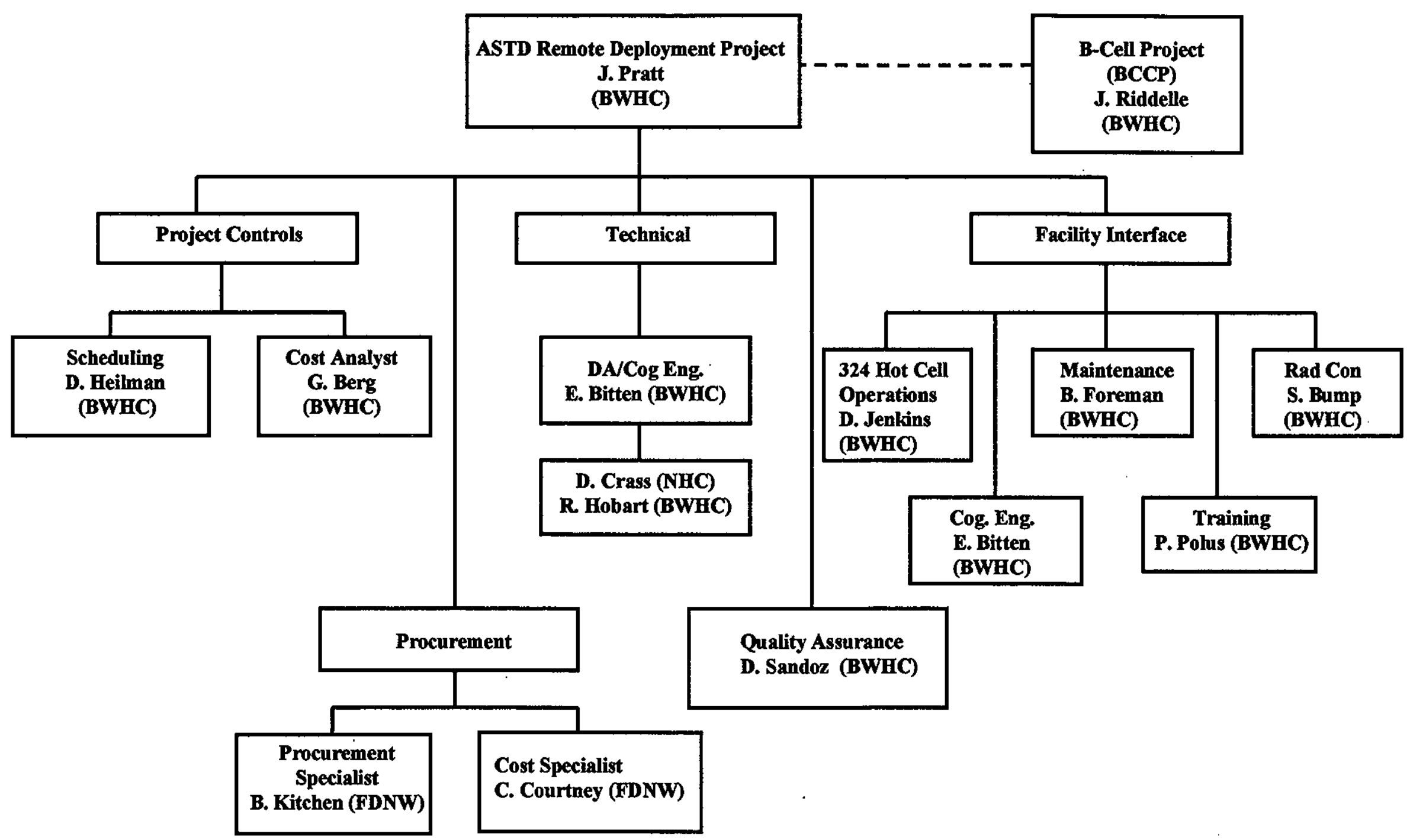


HNF-4991, Rev. 0

APPENDIX D SCHEDULE 


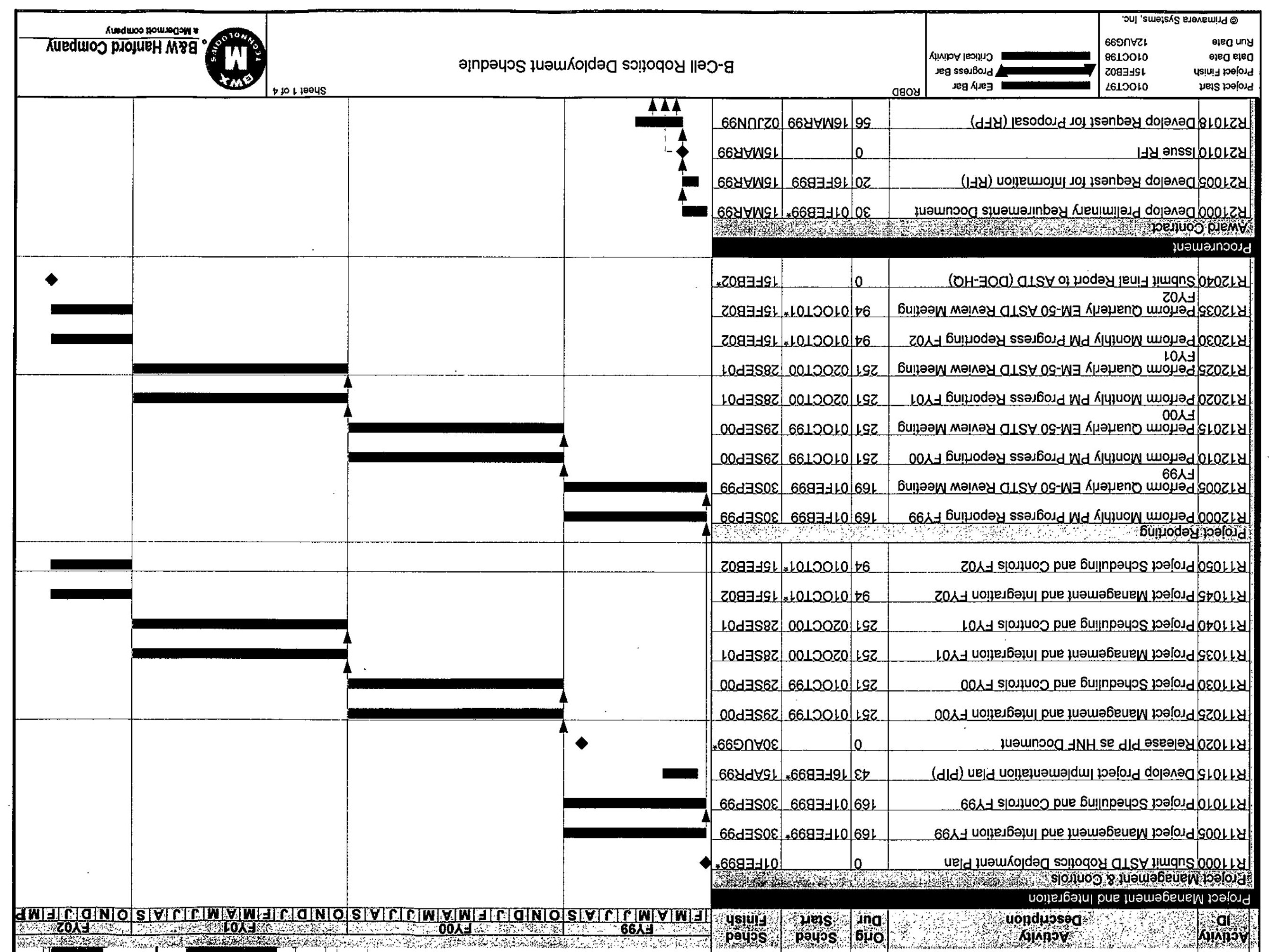




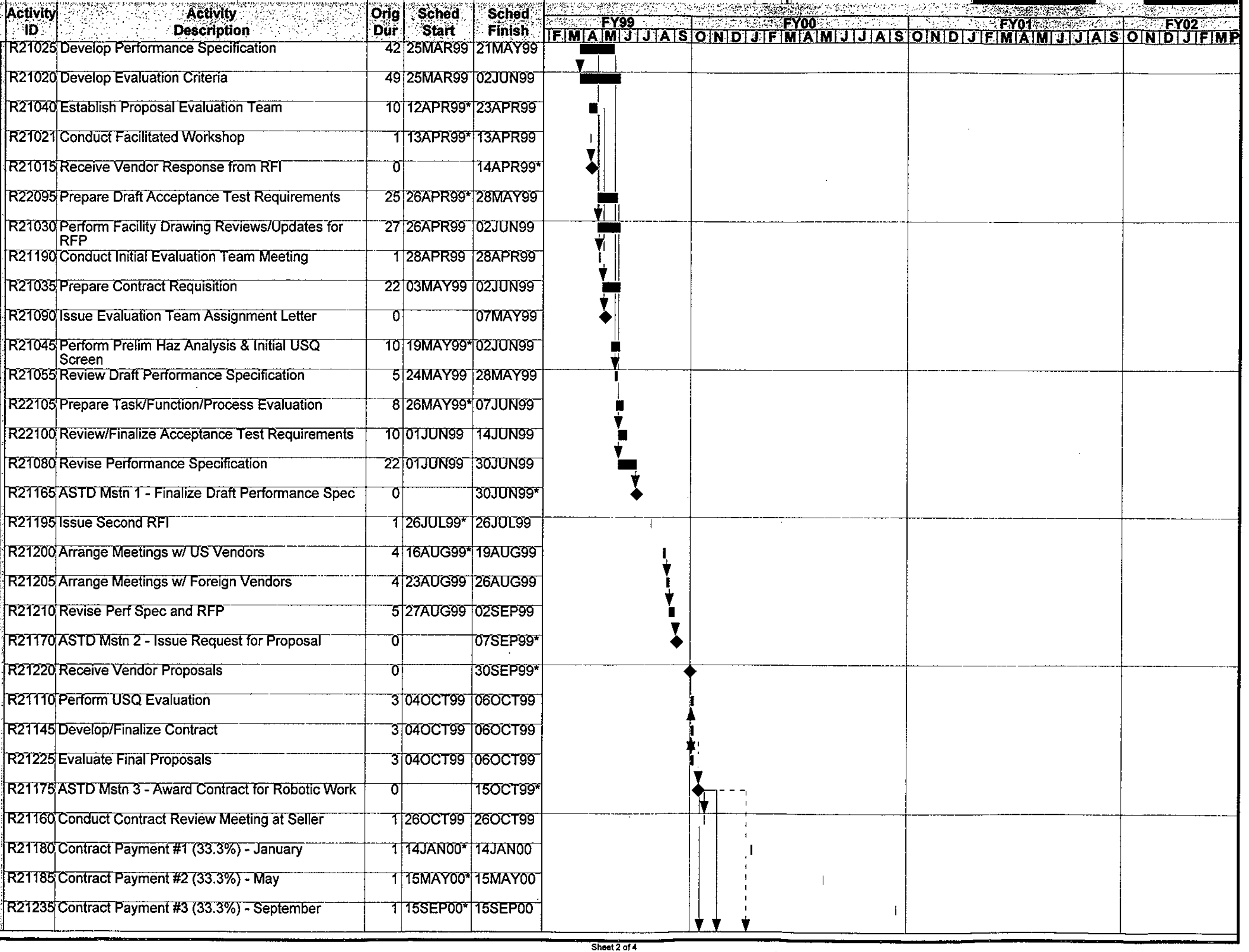




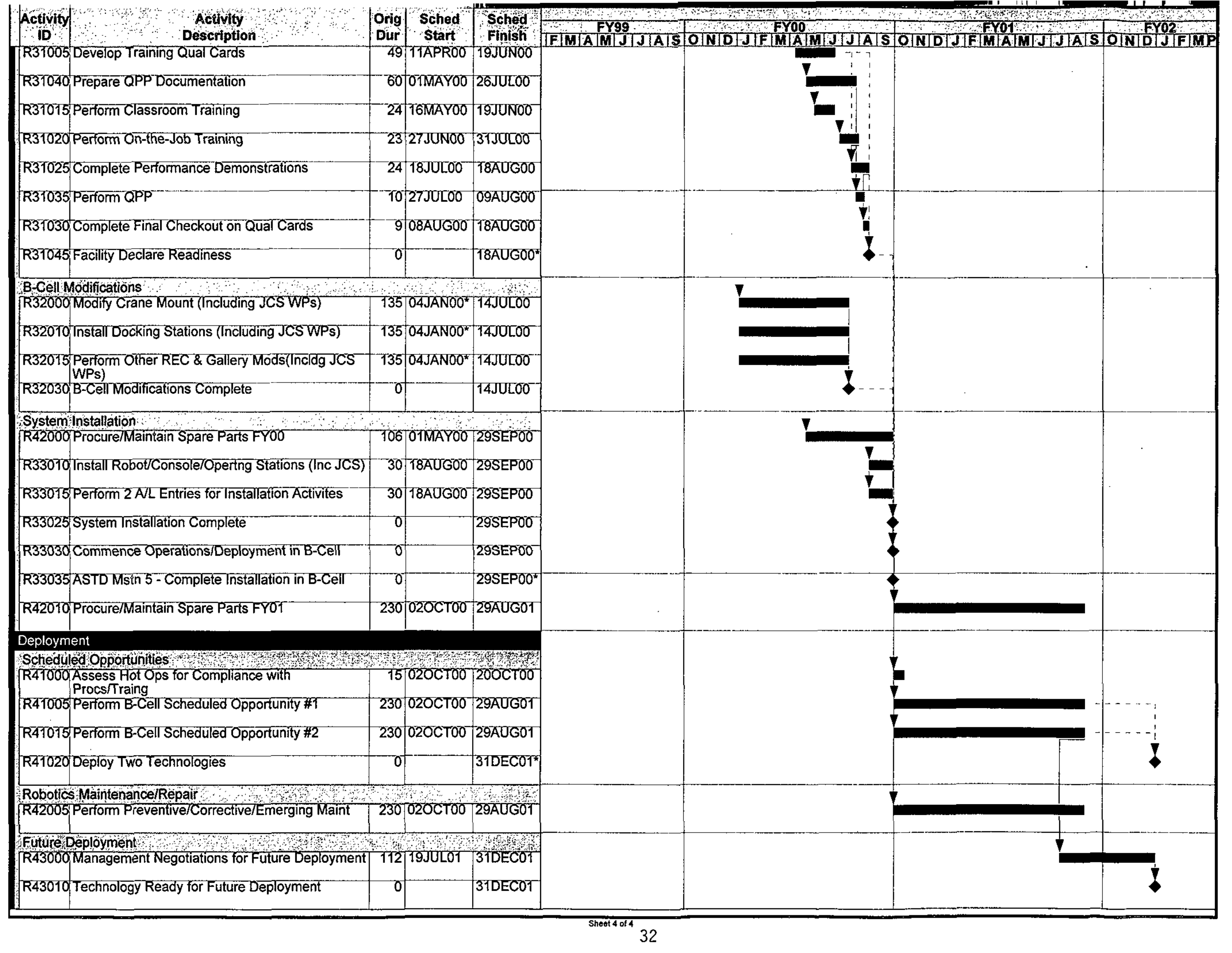

